\title{
IT Governance Framework Applied to SMEs
}

\author{
François Bergeron, TELUQ/Université du Québec, Québec City, Québec, Canada \\ Anne-Marie Croteau, Concordia University, Montreal, Québec, Canada \\ Sylvestre Uwizeyemungu, Université du Québec à Trois-Rivières, Trois-Rivières, Québec, \\ Canada \\ Louis Raymond, Université du Québec à Trois-Rivières, Trois-Rivières, Québec, Canada
}

\begin{abstract}
The need to effectively manage IT resources such that they enhance the business value of firms makes IT governance (ITG) an important issue for both IS researchers and practitioners. The purpose of this paper is to build a conceptual framework for ITG in small and medium-sized enterprises (SMEs). The authors first analyze the main theories applied in ITG research, and confront them with the specificities of SMEs. The authors then highlight the limits of those theories in SMEs context and discuss adaptations needed or alternative theories in such context. The resulting framework is then applied to generate a set of six research propositions on ITG in SMEs.
\end{abstract}

Keywords: $\quad$ Governance, Information Technology, Institutional Theory, Institutional Trust Theory, Network Governance Theory, Resource Dependency Theory, SME, Stewardship Theory, Upper Echelon Theory

\section{INTRODUCTION}

Given that some organizations achieve higher performance with their IT investments while others fail to do so (Gattiker \& Goodhue, 2004), the issue that matters now is to know under which conditions organizations create value from their IT (Kohli \& Grover, 2008).

It has been argued that IT governance (ITG), which "is about controlling the strategic impact of IT and its value delivery to the business" (Zarvić et al., 2012, p. 543) can make the difference (Nfuka, \& Rusu, 2011; Devos, et al., 2012; Wilkin, 2012). The need to effectively manage IT resources so that they can enhance the business value of firms makes of ITG an important issue and yet an uneasy task (Weill \& Ross, 2004; Van Grembergen \& De Haes, 2010). Indeed, the most important IT challenges faced by organizations now and in the future are less related to technology than to governance (Nfuka, \& Rusu, 2011).

The literature related to ITG in particular, and to corporate governance (CG) in general, 
has mobilized and proposed different theories and frameworks to explain the mechanisms of governance. However, most of those theories and frameworks are often criticized as being more appropriate for large enterprises (LEs) and less for small and medium-sized enterprises (SMEs), hence the call for revisiting existing theories and frameworks or for proposing alternative ones with in mind the specific realities of SMEs (Banham \& He, 2010). This call is important, all the more so that studies on ITG in SMEs are rather rare (Vogt et al., 2011; Alves et al., 2013). This paucity of studies does not mean, however, that ITG does not exist in the context of SMEs. Previous studies have shown that SMEs use IT in their basic activities and are expanding IT usage in more advanced processes (Raymond \& Croteau, 2006; Mardikyan, 2010; Ruivo, Oliveira \& Neto, 2012; Sila \& Dobni, 2012). As IT users, SMEs have to find ways to allocate IT-related responsibilities and to ensure IT-business alignment for increased business value, brief ways to practice ITG (Luftman et al., 2010). Given the important consequences IT can have on growth and survival of SMEs in a competitive market, we argue that ITG for SMEs is a necessity and must be researched.

The purpose of this paper is to build a conceptual framework for ITG in SMEs. To do so, we proceed in three phases. First, we analyze theories generally applied in ITG literature with in mind the specificities of SMEs, and we bring out salient limits of these theories with regards to the realities of SMEs. Second, we identify adaptations necessary to these theories to account for the SME's realities, and alternative theories better suited to its context. Third, building on the results of the precedent analysis we propose a conceptual framework for ITG in SMEs and related propositions that can be used as hypotheses for future research.

\section{THEORETICAL AND EMPIRICAL BACKGROUND}

In the literature, corporate governance (CG) is generally conceptualized with reference to the rights and responsibilities of different stakeholders in the firm, to the relationships among stakeholders with regards to the decisionmaking process, resolution of possible conflicts, and control of organizational resources, and to the means for setting corporate objectives and monitoring performance (Turlea et al., 2010). The OECD has proposed the following definition of CG which seems to have gained widespread popularity (Mason \& O’Mahony, 2008): "a set of relationships between a company's management, its board, its shareholders and other stakeholders [that] provides the structure through which the objectives of the company are set, and the means of attaining those objectives and monitoring performance are determined" (p. 32).

ITG has emerged since the $1990 \mathrm{~s}$ as a conceptualization of steering the use of IT within a company (Zarvić et al., 2012). It is now acknowledged that ITG is the responsibility of top management and an integral part of corporate governance (De Haes et al., 2013). This view is integrated in frameworks such as CoBIT 5 that establish good practices for ITG.

Definitions of ITG in the literature refer implicitly to the principal-agent problem which is central in the dominant agency theory in CG literature. In this perspective, a parallel is made between the alignment of executives' decisions to the owners' interests in CG and the alignment of IT management practices to the firm's needs in ITG. We define ITG as follows: ITG, a responsibility of top-management and an integral part of corporate governance, encompasses the decision rights and the accountability framework for encouraging desirable behavior in the use of IT, and ensuring that IT goals and objectives are realized in an efficient and effective manner (De Haes et al., 2013).

\section{SMES' SPECIFICITY REGARDING CG AND ITG}

Early previous studies have pointed out SMEs' specificities (Jennings \& Beaver, 1997; Raymond, Bergeron, \& Rivard, 1998; Torrès, 
\& Julien, 2005). Blili and Raymond (1993) grouped these specificities in five categories: environmental, organizational, decisional, psycho-sociological, and informational. Generally speaking, SMEs operate in local markets and exert little control over their environment, they rather bank on their flexibility to adapt to changing conditions in environment; they count on limited resources, financial and human, and they are characterized by a simple organic structure, developed around interests/abilities of key employees, and by a centralized management; their decision-making and strategic formulation processes are intuitive, adaptive, and short-term oriented; they are in almost all aspects overwhelmingly dominated by the owner-managers who cumulate the roles of entrepreneurship, ownership, and management; their internal and external information systems are generally simple and informal.

The specificity assumption of SMEs should, however, be cautiously considered. At least two cautions should be heeded. First, the statement of the specificities of SMEs does not mean that the group of SMEs is homogenous. The heterogeneity inside this group is a deep-seated phenomenon in the small business research field (Torrès \& Julien, 2005). With regard to ITG for example, one would assume that SMEs pertaining to different categories such as local, transition, and world-class SMEs which are characterized by different IT adoption patterns (Raymond and Croteau, 2006) would adopt different ITG mechanisms.

As second caution, the assumption of specificity should not be transformed into a universal principle (such as all SMEs are specific) ignoring that "[a] small business may sometimes not be, or no longer be, specific" (Torrès \& Julien, 2005, p. 360). Indeed, in some contexts, referred to as "denaturing contexts", the very characteristics that found the specificity of SMEs tend to disappear, giving place to an "anti-small business", that is a firm that, without growing in size, takes on all or most of the opposite features of small businesses (Messeghem, 2003; Torrès \& Julien, 2005). These authors, considering the denaturing potential of some contexts, plead for a contingent approach to SMEs specificity. This is exactly what have done Brouard and Di Vito (2008) by putting SMEs with multiple external shareholders on the same footing as (big) public companies with widespread shareholding, considering that agency conflicts in both situations would be similar.

Does the specificity of SMEs hold in the context of CG and ITG respectively? Can a SME embrace CG and ITG mechanisms and then keep the distinctive features of SMEs? At first sight, CG and ITG would appear counterintuitive for SMEs, in such they push for more structuring, planning, and formalization. Acknowledging this fact, we propose a conceptual framework for ITG governance that takes into account the specificities of SMEs, showing that there would be ITG mechanisms that are compatible with the SME's nature. In this research we use the OECD definition of a SME which is any firm that falls under the upper limit of 250 employees, in both manufacturing and service sectors (OECD, 2005).

\section{THEORIES APPLIED IN CG AND ITG RESEARCH}

Different theories applied into CG research have been applied in ITG research as well. The theories discussed in this paper results from a literature review we conducted. We do not pretend in the completeness of the list of existing theories; nevertheless, we believe that the main and most referred to theories are covered. The main theories are agency theory, stakeholder theory, power perspective, stewardship theory, resource dependency theory, network governance theory, institutional theory, upper echelon theory, institutional trust theory (Al Mamun, Yasser, \& Rahman, 2013).

In the following sub-sections we briefly present each theory and succinctly analyze its specific application in ITG empirical studies and its level of suitability to SMEs' realities. We begin with those that seem less applicable to ITG in the context of SMEs. 


\section{Agency Theory}

This theory is the overwhelmingly dominant school of thought both in academic research and practice (Mason \& O’Mahony, 2008). It focuses on problems arising from separation of ownership and control (Uhlaner et al., 2007). It embraces a narrow, shareholder-centric view of $\mathrm{CG}$, which reflects the traditional finance paradigm of shareholder value maximization as the main (if not the sole) goal of corporate management (Turlea, et al., 2010). Following agency theory reasoning, studies in ITG have analyzed the relationships between ownership and control structures of the firm and the IT performance (Karake, 1995; Ferguson et al., 2013).

The problem of applying this reasoning in the context of SMEs, at least as it has been applied in ITG in large enterprises (LEs) is threefold. First, this reasoning is based on the principal / agent problems that are less likely to happen in SMEs due to the overlapping of management and ownership in those firms (Banham \& He, 2010; Brunninge et al., 2007). Second, structures that are referred to in proposed governance mechanisms inadequately mirror the ones found in LEs as if SMEs were just scaled down LEs (Uhlaner et al., 2007). Third, due to the small size of SMEs, the information asymmetry is very low (Brouard \& Di Vito, 2008). Information asymmetry is at the basis of opportunistic behaviors that agency theory-related governance mechanisms seek to thwart. Therefore we consider that agency theory does not apply well to SMEs.

\section{Stakeholder Theory}

While agency theory focuses on the sole dual relationship between managers and shareholders, the stakeholder theory broadens constituencies, adding to managers and shareholders other groups of actors that may have a direct or indirect stake at the firm's operations (Talaulicar, 2010; Abraham, 2012). Stakeholder theory is inherently inscribed into ITG. Many ITG definitions "explicitly or implicitly refer to stakeholders either as ends of or as contributors to the ITG activities" (Messabia, \& Elbekkali, 2010, p. 981).

The stakeholder theory has been criticized as a perspective that can lead SMEs to implement policies with sub-optimal outcomes (Abor, \& Adjasi, 2007; Abor \& Biekpe, 2007). The pursuit of divergent stakeholders' interests such as environmental versus financial is less of an issue in SMEs than in LEs. As a "definitive stakeholder", the SME owner-manager is the most salient among all stakeholders, that is, the one whose claims will be given priority in ITG (Mitchell etal., 1997). Therefore the stakeholder theory does not apply so well to the reality of SMEs with regards to ITG.

\section{Power Perspective}

The power perspective is used in corporate governance to analyze potential conflicts of interests that may arise among different stakeholders, notably among executives, directors, and shareholders (Chen, 2007). With regard to ITG, this perspective is referred to analyze the relative influence of IT function comparatively to the influence of other business units in ITrelated decision processes (Xue et al., 2008; Weill \& Ross, 2005).

The potential conflicts opposing executives, directors, and shareholders that are at the core of the power perspective theory (Daily et al., 2003) are less likely to be observed in SMEs. Thus, this theory does not capture well the reality of SMEs with regards to ITG. The above theories that we assess as less applicable to ITG in SMEs are summarized in Table 1.

Among alternative theories that can be mobilized to study ITG in SMEs, we propose the following ones as more appropriate: stewardship theory, resources dependency theory, network governance theory, institutional theory, upper echelon theory, and institutional trust theory (Brunninge et al., 2007; Devos et al., 2012). Here are their key characteristics and why they seem more applicable to ITG for SMEs. They are summarized in Table 2. 
Table 1. Theories with lower applicability of ITG in SMEs

\begin{tabular}{|l|l|l|}
\hline \multicolumn{1}{|c|}{ Theories } & \multicolumn{1}{|c|}{$\begin{array}{c}\text { Key Issues with Regard to ITG } \\
\text { Mechanisms }\end{array}$} & \multicolumn{1}{c|}{ Reasons Why Lower Applicability to SMEs } \\
\hline Agency theory & Some cases of IT outsourcing & $\begin{array}{l}\text { - Principal / Agent problems less likely } \\
\text { (Brunninge, et al., 2007; Banham \& He, 2010) } \\
\text { - Reference to unlikely structures } \\
\text { (van Gils, 2005) } \\
\text { - Low information asymmetry } \\
\text { (Brouard \& Di Vito, 2008) }\end{array}$ \\
\hline $\begin{array}{l}\text { Stakeholder } \\
\text { theory }\end{array}$ & Predominant role of owner-manager & $\begin{array}{l}\text { Suboptimal outcomes } \\
\text { (Abor, \& Adjasi, 2007; Banham \& He, 2010) }\end{array}$ \\
\hline $\begin{array}{l}\text { Power } \\
\text { perspective }\end{array}$ & Predominant role of owner-manager & $\begin{array}{l}\text { Lower levels of power playing } \\
\text { (Fiegener et al., 2004) }\end{array}$ \\
\hline
\end{tabular}

\section{Stewardship Theory}

This theory is based on an assumption opposite to the agency theory's premise of opportunistic behavior as inherent to human nature. According to the stewardship theory, managers are naturally trustworthy, and seek to be good stewards of the corporate assets (Uhlaner et al., 2007; Nicholson \& Kiel, 2007; Del Baldo, 2012). With regard to ITG specifically, the stewardship theory may be more consistent with the nature of ITG because the managers' interests are perfectly aligned with the shareholders' interests, thanks to the overlapping of ownership and control in most SMEs (McGinnis et al., 2004; Brunninge et al., 2007).

\section{Resource Dependency Theory}

This theory is used in CG to explain the role of board of directors as a link to access to further resources available in the firm's environment (Nicholson \& Kiel, 2007). Board members extend the reach of an organization in its environment, and provide it with access to resources that would otherwise be out of reach or expensive (Daily et al., 2003). Research in this area focuses on the size and the composition of the boards as they may reflect the extent of exposure to external environments networks and access to various resources (Jackling \& Johl, 2009). The resource-dependency theory can be and has been specifically applied to ITG (Rasheed \&
Geiger, 2001; Xue et al., 2008). The resourcedependency theory fits well to the context of SMEs, particularly because most SMEs depend on external IT expertise (Devos et al., 2012).

\section{Network Governance Theory}

This theory involves a select, persistent and structured set of private firms and non-profit agencies engaged in creating, manufacturing or distributing products or services, based on implicit and open-ended contracts designed to adapt to their environmental specificities and to coordinate and safeguard exchanges (adapted from Jones et al., 1997). Based on the network governance theory, research on interorganizational ITG unveiled the two profiles of interorganizational ITG: contractual and consensual (Croteau et al., 2013). These profiles take into account the ITG structure, the process followed to make decisions, and the roles of participants involved in setting and promoting interorganizational mechanisms (Croteau $\&$ Bergeron, 2009). Given the more informal structure of SMEs, they have a lower number of hierarchical levels, a lower ratio of managers/ employees and they are at an earlier level (state) of interorganizational ITG maturity (Barthon \& Jepsen, 1997; Croteau \& Bergeron, 2009). It is therefore expected that SMEs will have a more informal and flatter interorganizational ITG structure, will be more dependent upon partners as to the choice and obligation of IT 
Table 2. Theories with higher applicability of ITG in SMEs

\begin{tabular}{|c|c|c|}
\hline Theories & $\begin{array}{c}\text { Key Issues with Regard to ITG } \\
\text { Mechanisms }\end{array}$ & $\begin{array}{c}\text { Reasons Why Lower Applicability to } \\
\text { SMEs }\end{array}$ \\
\hline Stewardship theory & $\begin{array}{l}\text { - No need for agency-based control } \\
\text { mechanisms } \\
\text { - Empowerment of owner-managers and } \\
\text { key employees }\end{array}$ & $\begin{array}{l}\text { Convergence of ownership and management } \\
\text { (Brunninge, et al., 2007) }\end{array}$ \\
\hline $\begin{array}{l}\text { Resource dependency } \\
\text { theory }\end{array}$ & $\begin{array}{l}\text { - Role of IT external partners } \\
\text { - Role of outside and independent } \\
\text { directors }\end{array}$ & $\begin{array}{l}\text { Limited internal resources (Devos et al., } \\
\text { 2012) }\end{array}$ \\
\hline $\begin{array}{l}\text { Network governance } \\
\text { theory }\end{array}$ & $\begin{array}{l}\text { - Pressures from partners to conform } \\
\text { - Support from the network }\end{array}$ & $\begin{array}{l}\text { - Pressure to formalize the network structure } \\
\text { - Pressure to implement controls } \\
\text { - Pressure to improve IT knowledge and } \\
\text { communication } \\
\text { - Need for partners' support }\end{array}$ \\
\hline Institutional theory & $\begin{array}{l}\text { Institutional pressures towards ITG } \\
\text { mechanisms adoption }\end{array}$ & $\begin{array}{l}\text { - Pressures towards IT innovations adoption } \\
\text { from the SME's networks (MacGregor, 2004; } \\
\text { Raymond et al., 2012) } \\
\text { - Little capacity of SMEs to resist to } \\
\text { pressures }\end{array}$ \\
\hline Upper echelon theory & $\begin{array}{l}\text { - IT-related roles and responsibilities for } \\
\text { owner-manager } \\
\text { - IT champion among key employees }\end{array}$ & $\begin{array}{l}\text { - Predominance of owner-managers } \\
\text { (Brunninge et al., 2007; Napoli, 2012) } \\
\text { - Important role of key employees } \\
\text { (Brunninge et al., 2007; Napoli, 2012) }\end{array}$ \\
\hline $\begin{array}{l}\text { Institutional trust } \\
\text { theory }\end{array}$ & $\begin{array}{l}\text { Moderating effect of institutional trust } \\
\text { between SME and external IT partner on } \\
\text { the adoption of ITG mechanisms. }\end{array}$ & $\begin{array}{l}\text { - Partnership based on trust (Devos et al., } \\
\text { 2012) } \\
\text { - Limited resources for agency-based controls } \\
\text { implementation (Huang et al., 2010) }\end{array}$ \\
\hline
\end{tabular}

control processes, and the interorganizational participants to ITG will be less in number yet more involved into their IT-related decisions and actions. It is thus expected that the more a SME is involved in external networks, the more it will implement ITG mechanisms. It will be under pressure to conform itself to its partners' practices and will rely on the network capacity to compensate for its lack of internal resources and capabilities (Xiaobao et al., 2013).

\section{Institutional Theory}

This theory considers that organizations are not just economic systems motivated by the pursuit of economic efficiency and performance, but are also social and cultural systems that seek to gain legitimacy in their environment by adjusting themselves to regulations, norms and values (Al Mamun et al., 2013; DiMaggio \& Powell,
1983). Institutional theory acknowledges the influence of an organization's environment on its IT structures and practices. More precisely, the intensity of institutional pressures will affect the IT department power, and will influence an organization's ITG patterns (Xue et al., 2008). Moreover, due to their size and to their limited resources, SMEs may be more influenced by their environment than LEs. Hence the institutional theory seems be suitable for analyzing the adoption of ITG practices in the SME's context (MacGregor, 2004; Mohnnak, 2007; Islamoglu \& Liebenau, 2007; Raymond et al., 2012).

\section{Upper Echelon Theory}

According to upper echelon theory, the characteristics of top-level managers play a crucial role in determining the strategic organizational outcomes and processes (Hambrick \& Mason, 
Figure 1. ITG in SMEs

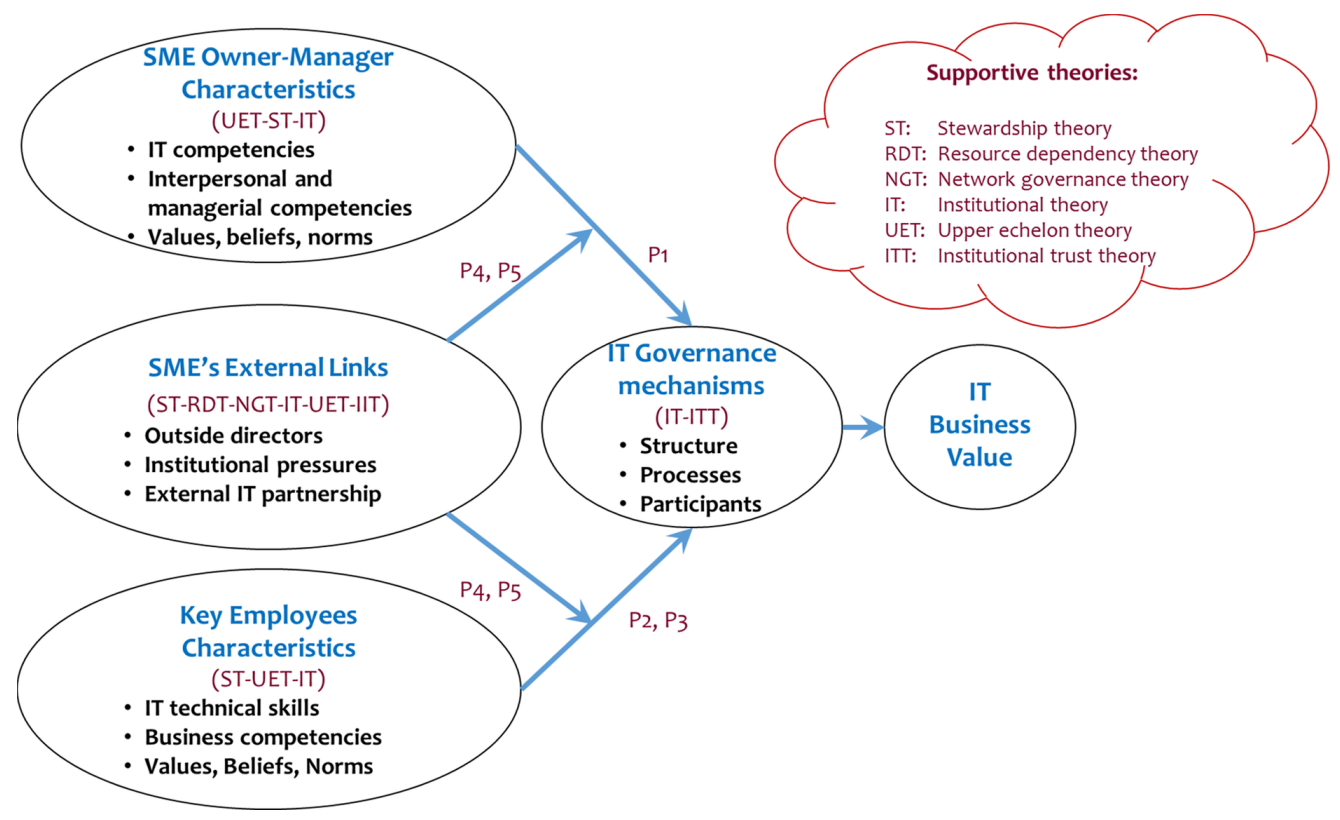

1984). The small size and the structural flexibility of SMEs intensify the involvement of top managers in almost all of the firm's activities, and their influence is thus stronger than it can be in LEs (Brunninge et al., 2007). The upper echelon theory offers new theoretical lens through which ITG mechanisms in SMEs can be analyzed. The focus shifts from agency-related levels of analysis (ownership structure, board of directors, incentive compensation) towards the SME's top management team (or key employees). The upper echelon theory has been mainly used to analyze the strategic changes in SMEs (Brunninge et al., 2007; Napoli, 2012), but it is quite appropriate for ITG as well. The values, norms, backgrounds, and interests of top-level managers of SMEs may explain their readiness and their predisposition to adopt certain forms of ITG mechanisms and to reject others.

\section{Institutional Trust Theory}

This theory is an interesting alternative theoretical perspective to agency theory and it is suitable to the context of SMEs as well. Instead of relying on agency-based control mechanisms to deter opportunistic behavior in IT collaboration relationships, SMEs may develop a partnership based on trust, which "can be seen as a coordinating mechanism, based on shared moral values and norms" (Devos et al., 2012, p. 210). Trust reduces the need to resort to structured controls, such as steering committees, management guidelines, policies and procedures, or to comprehensive outcome-based contracts, for which SMEs may not be well-equipped to deal with given their financial constraints and their limited capabilities in terms of internal IT-related human resources (Huang etal., 2010).

\section{CONCEPTUAL FRAMEWORK}

The preceding analysis shows that when analyzing ITG in SMEs, we need to take into account theories that are more appropriate for SMEs. Building on such theories as discussed in the precedent section, we propose a conceptual framework of ITG in SMEs with the corresponding supportive theories by constructs, as illustrated in Figure 1. 
In this framework, the SME's ownermanager and key (internal) employees are the main actors. The inclusion of the SME's owner-manager characteristics in the conceptual framework of ITG in SMEs is based on the stewardship theory and the upper echelon theory, which both acknowledge the SME's owner-manager's tight grip on any major organizational activities and decisions. Besides, the primary role played by owner-managers in the context of SMEs is unanimously acknowledged in the small business literature.

The inclusion of the SME's key employees is based on the stewardship theory and the upper echelon theory as well: key employees' influence is inversely proportional to the size of their organization, so the role of key employees in any major decisions would be greater in SMEs than in LEs. Shared values, beliefs and norms of both the owner-manager and the key employees are based on the institutional theory.

The proposed framework also assumes that in their decision with regard to ITG mechanisms, the SME's owner-manager and key employees will be to some extent influenced by its external links. This assumption is based concurrently on the resource-dependency theory, the network governance theory, the institutional theory, and the institutional trust theory. In accordance with the resource-dependency theory and network governance theory, the access to external resources through either independent and outside directors or IT external partners would influence the SME's owner-manager and key employees with respect to their ITG decisions.

The network governance theory and the literature on interorganizational governance of IT suggest that governance mechanisms related to structure, processes and participants lead to higher competitive advantage or IT business value. The network governance theory also suggests that SMEs involved in networks are likely to be influenced by their business partners in adopting ITG mechanisms. According to institutional theory, mimetic, normative, and coercive pressures would be exerted on the SME's main actors towards the implementation of the same ITG mechanisms adopted by organi- zations evolving in the SME's environment. As for the theory of institutional trust, it allows to take into account the moderating effect of trust between a SME and its IT external partners on the level of ITG mechanisms implementation: high levels of trust reduce the need for ownermanagers and key employees to implement agency theory-inspired ITG mechanisms.

So, the proposed conceptual framework is composed with five main groups of factors. At the center, there is the group of ITG mechanisms. Their adoption is directly or indirectly determined by three groups of factors: the SME's owner-manager's characteristics, its key employees' characteristics and the SME's external links. IT business value, as the outcome ofITG mechanisms, is the last group (discussed later in the section on the consequences of ITG mechanisms).

\section{IT GOVERNANCE MECHANISMS IN SMES}

Having its roots in the network governance theory (Jones, 1997; Barthon et al., 1997), ITG and interorganizational ITG generally classifies ITG mechanisms into three dimensions: structures, processes, and participants (Croteau \& Bergeron, 2009; Croteau et al., 2013; Ko \& Fink, 2010). Sometimes, participants is also referred to as relational mechanisms (De Haes \& Van Grembergen, 2006; Wilkin, 2012; Mohamed \& Singh, 2012). The structure dimension emphasizes control and coordination and refers to the organization of IT function, to its roles and responsibilities, brief, to the formal and rational units and mechanisms put in place to carry out IT-related decisions and activities in organizations; structure refers to the locus of authority with regards to IT decision-making, in other words it determines who act and with which resources (Croteau \& Bergeron, 2009). The processes dimension emphasizes control and sustainable capability, and refers to tools, techniques, frameworks or standards combined to ensure IT-business strategic alignment and to track IT performance achievements. The 
participants dimension refers to the persons at various levels and functions who take part in leadership, training and sharing, who actively participate, collaborate, communicate, and get involved in order to disseminate ITrelated policies, principles and outcomes. ITG would be even more important in a network or interorganizational environment due to the partners requirements in terms of a minimum threshold of quality, uniformity and reciprocity of IT mechanisms needed to create value for all network members. In this situation, the network strength is as high as the weakest of its link. Much adaptation will therefore have to be made to SMEs specificities.

Some highly-formalized ITG mechanisms are less suitable to rather organic and loosely structured SMEs (Jennings \& Beaver, 1997). Basic ITG mechanisms are likely to be found in SMEs. These ITG mechanisms are not necessarily denaturing. Structure-related ITG mechanisms such as CIO on board and IT steering committee (De Haes \& Van Grembergen, 2006) are less likely to be in place in SMEs, as their structural ITG capability is likely to be assumed by the owner-manager. Clear IT-related roles and responsibilities of the owner-manager are thus necessary as structural governance mechanism in this case (Wilkin, 2012). Instead of the formal CIO function, a SME is likely to rely on an IT champion, a much more informal role and yet a very important one for its IT-related activities (Pollard, 2003). SMEs may also rely on external expertise to compensate their lack of expertise internally. The IT champion will play a determinant role in the relationship between a SME and its IT external expert.

For process-related mechanisms such as externally developed standards, tools, techniques, or frameworks like COBIT, ITIL, ISO17799 which are highly formalized and certification oriented, SMEs are not either well equipped (Ko \& Fink, 2010). Without necessary resorting to highly developed tools, SMEs have to find ways to align their IT projects to their strategic business and to track IT business value creation. Otherwise, overwhelmed by operational imperatives as they tend to be,
SMEs may lose sight of long term and strategic imperatives in their IT decision-making. So, one would consider IT strategic alignment and IT performance tracking as key process-related ITG mechanisms in SMEs.

As for participants, relational mechanisms such as business/IT co-location and active participation and collaboration between key stakeholders do not need to be formally implemented in SMEs as they are naturally evident in such context (Wilkin, 2012). However, for an effective collaboration between participants (Peterson, 2004), people involved in ITG need to develop mutual understanding which can be reached through IT training, and proper communication for developing awareness and understanding of business/IT objectives.

\section{ANTECEDENTS OF ITG MECHANISMS}

In our framework, the adoption of ITG mechanisms is directly determined by both SME owner-manager's characteristics and key employees' characteristics, and indirectly affected by SME's external links. In other words, the relationship between, on one hand the ownermanager's characteristics and the key employees' characteristics, and on the other hand the adoption of ITG mechanisms is moderated by the SME's external links.

\section{SME's Owner-Manager}

Studies on SMEs have acknowledged the central role of the entrepreneur or owner-manager in shaping the firm. As the principal stakeholder concurrently assuming multiple roles, he/she is involved in almost if not all major decisions that affect the firm for better or worse. His/her characteristics will then be determinant. Banking on previous studies, we put these characteristics in three main categories: IT-related competencies (Caldeira \& Ward, 2003; Wainwright et al., 2005; Scupola, 2008; Cragg et al., 2011), interpersonal and managerial competencies (Kraemmergaard \& Rose, 2002; Bassellier \& Benbasat, 2004) and personal values, beliefs, 
and norms (Ramdani, et al., 2009; Del Baldo, 2012).

IT-related competencies of an ownermanager are important in that they will shape not only his/her understanding of opportunities of IT usage in business activities, but also his or her expectations with regards to how IT activities should be managed. These understanding and expectations will lead to the IT adoption decision, and more important, to the creation of facilitating conditions for the actual IT implementation and use (Scupola, 2008). ITG mechanisms can be viewed as facilitating conditions meant to leverage IT for achieving business goals.

Interpersonal and managerial competencies will help the owner-manager to effectively communicate his/hervision ofITG mechanisms, motivate and get employees to adhere to that vision, overcome change resistance, and meet the scope, time, and goal objectives throughout the implementation phases of ITG mechanisms. Adapting Kraemmergaard and Rose's (2002) and Bassellier and Benbasat's (2004) definitions to the context of ITG, we retain leadership, interpersonal communication, human resource, change management, and project management as part of interpersonal and managerial competencies.

Another determinant factor that would sway an owner-manager's decision in favor or not of ITG mechanisms adoption is the level of compatibility between these mechanisms and his/hervalues, beliefs, and norms. The notion of compatibility, which refers to the perception of consistence of an innovation (ITG mechanisms in this case) with regards to values, experiences, beliefs, and needs of would-be adopters, is important, especially in small firms (Ramdani et al., 2009). Owner-managers will obviously willingly push for adoption of ITG mechanisms that are compatible with their values, beliefs, and norms.

Considering the precedent considerations, the following proposition can be stated:

P1. Greater competencies (IT-related, interpersonal and managerial) of the SME's owner- manager and higher levels of perceived compatibility of his/her values, beliefs, and norms with ITG mechanisms will positively influence the implementation of ITG mechanisms in a SME.

\section{SME's Key Employees}

Notwithstanding the key role of the entrepreneur or the owner-manager in all major decisions, key employees' influence in SMEs is likely to be paramount. This major influence stems from the fact that small firms tend to be structured around key employees' abilities and interests (Jennings \& Beaver, 1997). It is also due to the small size and organizational flexibility of SMEs (Brunninge et al., 2007) that do not restrict key employees in narrowly-defined roles. The paramount influence of the SMEs' key employees is in line with the upper echelon theory (Hambrick \& Mason, 1984). The characteristics of a SME's key employees have to be taken into consideration in order to understand the adoption of ITG mechanisms in the firm. Based on previous studies (Kraemmergaard \& Rose, 2002; Bassellier et al., 2003), these characteristics are grouped into three main categories: (1) IT technical skills, (2) business competencies, and (3) values, beliefs, and norms.

At the level of key employees, IT technical skills required are more than a certain level of comfort with IT as is the case for owner-manager's IT knowledge. IT technical skills of key employees are a reflection of their IT-related explicit knowledge with regards to technology, applications, system development, IT management, access to IT knowledge. IT technical skills also include their IT-related tacit knowledge, that is experience in IT projects and experience in the management of IT (Bassellier et al., 2003). While owner-manager's IT knowledge play a role in the decision to adopt IT, IT technical skills at the key employees level are indispensable for the actual implementation and effective use of IT (Raymond et al., 2012). We would here assume the same pattern applies to ITG mechanisms adoption and implementation. 
So, for this study we define business competencies of key employees as the knowledge and skills of key employees of a SME related to their understanding the business domain and the specific organizational context. The business domain-specific competencies refer to the knowledge of the production system of a firm's industry, the ability to recognize the firm's challenges and opportunities, including the potential of IT leverage for enhancing business processes. The organization-specific competencies are about the acute acquaintance of the firm's functioning (e.g. power distribution, structures), specificities (e.g. culture and history), and partnership. Key employees with stronger business competencies (business domain-specific and organizational-specific) are more likely to better understand the potential of IT usage in business activities and the necessity to adopt ITG mechanisms for achieving higher IT business value.

As in the case of owner-managers, values, beliefs, and norms of key employees of a SME will affect ITG mechanisms adoption. Shared cognitive characteristics (such as values, beliefs, and norms) will be conducive to consensus among team members which in turn will facilitate the introduction of strategic change in SMEs (Brunninge et al., 2007). This can be seen as a positive factor for ITG mechanisms adoption. But according to institutional trust theory, shared values and norms may reduce the need of formalized mechanisms (Devos et al., 2012). So, we would argue that shared values, beliefs, and norms among the SME's key employees will accelerate the process of ITG mechanisms adoption (pace) while reducing the diversity of ITG mechanisms adopted. We would also argue that the SME's key employees will favor the adoption of ITG mechanisms they deem compatible with their values, beliefs, and norms over others deemed less compatible.

From the above developments, the two following propositions can be stated:

P2. Greater competencies (IT technical skills, business competencies) of the SME's key employees and higher levels of perceived compatibility of their values, beliefs, and norms with ITG mechanisms will positively influence the implementation of ITG mechanisms in a SME.

P3. The more the values, beliefs, and norms are shared among a SME's key employees, the more a SME will easily adopt and implement ITG mechanisms (quick pace), and the less diversified ITG mechanisms will be.

\section{SME's External Links}

In SMEs, decisions are mainly made by the owner-manager assisted by key employees. However, in their decision-making process, they may be swayed one way or another by external stakeholders. Following the literature review, we retained four sources of influence that can affect the decision to adopt ITG mechanisms: outside and independent directors, institutional pressures, IT external partnership and the network members.

We have already underscored that, in most SMEs, board of directors are either inexistent or purely formal, or sometimes used to serve the owner-manager's purposes (Fiegener et al., 2004; van Gils, 2005; Brouard \& Di Vito, 2008). Yet, in accordance with the resourcedependency theory, having a board on which sit a number of external directors increases a firm's exposure to external environment networks and its convenient access to valuable resources (Jackling \& Johl, 2009). The latter's independence vis-à-vis the owner-manager (and key employees) gives them much more latitude in their supervision role of the firm's management. So, SMEs are compelled to adopt boards with a great number of outside and independent directors (Abor \& Adjasi, 2007). This would prevent them from developing "a myopic and narrow view" that stalls change (Brunninge et al., 2007, p. 299). Outside and independent directors would influence ownermanagers and key employees towards ITG mechanisms adoption.

Institutional theory posits that changes in organizations are determined more by external or environmental pressures than "rational" deci- 
sions by internal actors (owner-managers and key employees) (DiMaggio \& Powell, 1983). In accordance with the institutional perspective, it has been found that the diffusion of corporate social responsibilities in SMEs is linked to the extent at which these SMEs are embedded in a network of local socio-economic institutions (Del Baldo, 2012). Similarly, a SME's network ties will play a role in deciding the owner-manager and key employees to embrace ITG mechanisms that are in place in other organizations within the network. Besides, inter-organizational exchanges entail task and function interdependence that requires a great deal of coordination (Croteau \& Bergeron, 2009). Challenges related to the coordination of business partners which are more or less different with regard to various organizational aspects (strategy, processes, structure, IT infrastructure and architecture) incite each other to put in place governance mechanisms (Croteau $\&$ Bergeron, 2009). In the same vein, compared to the local SMEs, world-class SMEs would need more ITG mechanisms due to their being involved in more extended networks (Raymond \& Croteau, 2006).

It is almost a truism to say that most SMEs lack internal IT expertise. To compensate this, they mainly rely on IT external expertise. Somehow, this dependence put a SME in a situation of inter-organizational ITG. Studying profiles of inter-organizational ITG, Croteau et al. (2013) proposed a continuum with at one end the contractual profile, and at the other, the consensual profile: in contractual profiles, "organizations are involved in a legal relationship with their outsourcers", while consensual profiles are characterized by "a collaborative and cooperative approach" (p. 36). Potential opportunistic behaviors are fought mainly through the formalization of commitments in contractual profiles, and through mutual trust in consensual profiles. Contractual profiles are consistent with agency theory according to which, as previously stated, a SME would adopt ITG mechanisms to deter opportunistic behavior from the external expert. We have seen however, in accordance with the theory of institutional trust, that some SMEs, ill-equipped for developing structured controls or outcome-based contracts, will instead seek a partnership based on trust (Devos et al., 2012). So, an external partnership based on trust will reduce the need to resort to formalized ITG mechanisms in SMEs.

All these considerations related to the SME's external links lead to the following propositions:

P4. A SME's external links through outside and independent directors, networks, and IT partners will have a positive impact on the owner-manager's and key employees' decision to adopt ITG mechanisms.

P5. The higher the level of institutional trust between a SME and its IT external partner, the less its owner-manager and key employees will be swayed towards ITG mechanisms adoption.

\section{CONSEQUENCES OF ITG MECHANISMS}

It has been suggested that there may be a positive correlation between ITG mechanisms and different organizational performance measures as captured into Kaplan and Norton's balanced scorecard framework (Mohamed \& Singh, 2012). Bradley et al. (2012) have established that ITG has a positive impact on different measures of hospital performance. The underlying assumption is that effective ITG would enhance IT impacts on the organizational performance.

The idea that the ultimate effectiveness of ITG mechanisms adopted in organizations should be appreciated in terms of IT contribution to business value (IT business value) seems to be a largely shared understanding in ITG literature (Zarvić et al., 2012). IT business value is defined as "the organizational performance impacts of information technology at both the intermediate process level and the organization-wide level, and comprising both efficiency impacts and competitive impacts" (Melville et al., 2004, p. 287). More precisely, Weill and Ross (2005) suggested assessing the ITG effectiveness 
against the achievement of four IT-enabled organizational objectives: "cost-effectiveness, asset utilization, business growth and business flexibility" (p. 26).

As the effectiveness of IT initiatives and investments is one of the priorities of ITG (Bradley et al., 2012), any failure with regards to IT initiatives hints to the failure of ITG. For example, failure of outsourced information systems may be seen as a failure of ITG (Devos et al., 2012). In the same way, the underexploitation of IT business value in SMEs can be blamed on weaknesses of their ITG (Wilkin, 2012). Even a weak interorganisational ITG can lead to disastrous results in terms of competitiveness. So, the adoption of ITG mechanisms may have a positive impact on IT business value in SMEs, hence the following proposition:

P6. The adoption of ITG mechanisms in a SME will improve its IT business value.

\section{CONTROL VARIABLES: SIZE, SECTOR, AND AGE}

We previously underscored the necessity of carefully considering the heterogeneous nature of SMEs. All of these enterprises share some particularities, but they may also present some differences due to their size (very small-, small-, medium-sized), industry sector, or their age. All these factors are taken into account in the proposed research framework as control variables.

The size of firms (in terms of the number of employees or in terms of revenues) is generally positively associated with the adoption of innovations (Ko et al., 2008; Pekovic, 2010). More precisely, in the field of ITG, it has been advanced that there may be a positive correlation between the firm's size and ITG effectiveness (Mohamed \& Singh, 2012). The same authors posit that organizations operating in information intensive sectors or in sectors characterized by high levels of uncertainty are more likely to effectively implement ITG mechanisms than organizations in less information intensive sectors, or in less uncertain environments. The firm's age can also explain differences between SMEs with regard to ITG mechanisms adoption. After reporting mixed results in literature on this topic, Mohamed \& Singh (2012) formulate the hypothesis that a firm's age would be negatively correlated with ITG effectiveness.

\section{CONCLUSION}

Theories and frameworks generally referred to in the field of CG in general, and in ITG in particular, have mainly been developed in the context of large enterprises. In this study we analyzed the main theories applied in CG and ITG research, and confronted them with the specificities of SMEs. This exercise allowed us to highlight the limits of these theories in the SME's context, and to discuss adaptations needed or alternative theories in such context. Building on these developments, we then proposed a conceptual framework of ITG in SMEs.

We have shown that the mainstream agency theory does not fare well when applied in the context of SMEs. So, the proposed conceptual framework is based on a combination of alternative theories: upper echelon theory, stakeholder theory, resource-dependence theory, the network governance theory, institutional theory, and the theory of institutional trust. In accordance with the now abundant literature on SMEs, the conceptual framework acknowledges the central role played by the owner-manager in all major decisions of the firm. In accordance with the upper echelon theory, the role of the SME's key employees (or the top-management team) is also acknowledged in the conceptual framework proposed. Together, resourcedependency theory, the network governance theory, the institutional theory and the theory of institutional trust have been referred to for propositions related to the role of the SME's external links in its decision towards ITG mechanisms adoption.

In taking the SME's specificities into account, we followed the previous research recommendation that size is one of the contingencies that must be heeded when designing 
a mix of structures, processes, and relational mechanisms for an ITG framework (Pollard, 2003). The six propositions presented in this paper may thus serve as initial hypotheses for empirical verification. This conceptual paper is a first step in our research. In the next step, case studies will be conducted to refine the conceptual framework, followed by a survey to test the framework.

\section{REFERENCES}

Abor, J., \& Adjasi, C. K. D. (2007). Corporate governance and the small and medium enterprises sector: Theory and implications. Corporate Governance, 7(2), 111-122. doi:10.1108/14720700710739769

Abor, J., \& Biekpe, N. (2007). Corporate governance, ownership structure and performance of SMEs in Ghana: Implications for financing opportunities. Corporate Governance, 7(3), 288-300. doi:10.1108/14720700710756562

Abraham, S.E.(2012). Information technology, an enablerincorporategovernance. Corporate Governance, 12(3), 281-291. doi:10.1108/14720701211234555

Al Mamun, A., Yasser, Q. R., \& Rahman, M. A. (2013). A discussion of the suitability of only one vs. more than one theory for depicting corporate governance. Modern Economy, 4(1), 37-48. doi:10.4236/ me.2013.41005

Alves, C. R. C., Riekstin, A. C., Carvalho, T. C. M. B., \& Vidal, A. G. R. (2013). IT governance frameworks: A literature review of Brazilian publications. Proceedings of the International Conference on Information Resources Management (CONF-IRM), Natal, Brazil, May 22-24, 1-14.

Banham, H., \& He, Y. (2010). SME governance: Converging definitions and expanding expectations. International Business \& Economics Research Journal, 9(2), 77-82.

Barthon, P., \& Jepsen, B. (1997). How time affects transaction costs and relational governance in the distribution channel: A review and research proposition. Management Research News, 20(6), 14-29. doi:10.1108/eb028566

Bassellier, G., \& Benbasat, I. (2004). Business competence of information technology professionals: Conceptual development and influence on IT-business partnership. Management Information Systems Quarterly, 28(4), 673-694.
Bassellier, G., Benbasat, I., \& Reich, B. H. (2003). The influence of business managers' IT competence on championing IT. Information Systems Research, 14(4), 317-336. doi:10.1287/isre.14.4.317.24899

Blili, S., \& Raymond, L. (1993). Information technology: Threats and opportunities for small and medium-sized enterprises. International Journal of Information Management, 13(6), 439-448. doi:10.1016/0268-4012(93)90060-H

Bradley, R. V., Byrd, T. A., Pridmore, J. L., Thrasher, E., Pratt, R. M., \& Mbarika, V. W. (2012). An empirical examination of antecedents and consequences of IT governance in US hospitals. Journal of Information Technology, 27(2), 156-177. doi:10.1057/jit.2012.3

Brouard, F., \& Di Vito, J. (2008). Identification des mécanismes de gouvernance applicables aux PME. $9^{\text {ème }}$ Congrès International Francophone en Entrepreneuriat et PME, Université Louvain-La-Neuve, Belgique, 1-19.

Brunninge, O., Nordqvist, M., \& Wiklund, J. (2007). Corporate governance and strategic change in SMEs: The effects of ownership, board composition and top management teams. Small Business Economics, 29(3), 295-308. doi:10.1007/s11187-006-9021-2

Caldeira, M. M., \& Ward, J. M. (2003). Using resource-based theory to interpret the successful adoption and use of information systems and technology in manufacturing small and medium sized enterprises. European Journal of Information Systems, 12(2), 127-141. doi:10.1057/palgrave.ejis.3000454

Chen, D. (2007). The behavioral consequences of CEO-board trust and power relationships in corporate governance. Business Renaissance Quarterly, 2(4), 59-75.

Cragg, P., Caldeira, M., \& Ward, J. (2011). Organizational information systems competences in small and medium-sized enterprises. Information \& Management, 48(8),353-363. doi:10.1016/j.im.2011.08.003

Croteau, A.-M., \& Bergeron, F. (2009). Interorganizational governance of information technology. 42nd Hawaii International Conference on System Sciences, Big Island, Hawaii, 1-8.

Croteau, A.-M., Bergeron, F., \& Dubsky, J. (2013). Contractual and consensual profiles for an interorganizational governance of information technology. International Business Research, 6(9), 30-43. doi:10.5539/ibr.v6n9p30 
Daily, C. M., Dalton, D. R., \& Cannella, A. A. Jr. (2003). Corporate governance: Decades of dialogue and data. Academy of Management Review, 28(3), $371-382$.

DeHaes, S., \& Van Grembergen, W. (2006). Information technology governance best practices in Belgian organizations. 39th Hawaii International Conference on System Sciences, Kauai, 1-7.

De Haes, S., Van Grembergen, W., \& Debreceny, R. S. (2013). COBIT 5 and enterprise governance of information technology: Building blocks and research opportunities. Journal of Information Systems, 27(1), 307-324. doi:10.2308/isys-50422

Del Baldo, M. (2012). Corporate social responsibility and corporate governance in Italian SMEs: The experience of some spirited businesses. Journal of Management \& Governance, 16(1), 1-36. doi:10.1007/s10997-009-9127-4

Devos, J., Van Landeghem, H., \& Deschoolmeester, D. (2012). Rethinking IT governance for SMEs. Industrial Management \& Data Systems, 112(2), 206-223. doi:10.1108/02635571211204263

DiMaggio, P. J., \& Powell, W. W. (1983). The iron cage re-visited: Institutional isomorphism and collective rationality in organizational fields. American Sociological Review, 48(2), 147-160. doi:10.2307/2095101

Ferguson, C., Green, P., Vaswani, R., \& Wu, G. (2013). Determinants of effective information technology governance. International Journal of Auditing, 17(1), 75-99. doi:10.1111/j.10991123.2012.00458.x

Fiegener, M. K., Brown, B. M., Dreux, D. R., \& Dennis, W. J. (2004). CEO stakes and board composition in small private firms. Entrepreneurship Theory and Practice, 28(4), 5-24.

Gattiker, T. F., \& Goodhue, D. L. (2004). Understanding the local-level costs and benefits of ERP through organizational information processing theory. Information \& Management, 41(4), 431-443. doi:10.1016/S0378-7206(03)00082-X

Hambrick, D. C., \& Mason, P. A. (1984). Upper echelons: The organization as a reflection of its top managers. Academy of Management Review, 9(2), 193-206.

Huang, R., Zmud, R. W., \& Price, R. L. (2010). Influencing the effectiveness of IT governance practices through steering committees and communication policies. European Journal of Information Systems, 19(3), 288-302. doi:10.1057/ejis.2010.16
Islamoglu, M., \& Liebenau, J. (2007). Information technology, transaction costs and governance structures: Integrating an institutional approach. Journal of Information Technology, 22(3), 275-283. doi:10.1057/palgrave.jit.2000107

Jackling, B., \& Johl, S. (2009). Board structure and firm performance: Evidence from India's top companies. Corporate Governance, 17(4), 492-509. doi:10.1111/j.1467-8683.2009.00760.x

Jennings, P., \& Beaver, G. (1997). The performance and competitive advantage of small firms: A management perspective. International Small Business Journal, 15(2), 63-75. doi:10.1177/0266242697152004

Jones, C., Hesterly, W. S., \& Borgatti, S. (1997). A general theory of network governance: Exchange conditions, and social mechanisms. Academy of Management Review, 22(4), 911-945.

Karake, Z. A. (1995). Information technology performance: Agency and upper echelon theories. Management Decision, 33(9), 30-37. doi:10.1108/00251749510098964

Ko, D., \& Fink, D. (2010). Information technology governance: An evaluation of the theory-practice gap. Corporate Governance, 10(5), 662-674. doi:10.1108/14720701011085616

Ko, E., Kim, S. H., Kim, M., \& Woo, J. Y. (2008). Organizational characteristics and the CRMadoption process. Journal of Business Research, 61(1), 65-74. doi:10.1016/j.jbusres.2006.05.011

Kohli, R., \& Grover, V. (2008). Business value of IT: An essay on expanding research directions to keep up with the times. Journal of the Association for Information Systems, 9(1), 23-39.

Kraemmergaard, P., \& Rose, J. (2002). Managerial competences for ERP journeys. Information Systems Frontiers, 4(2), 199-211. doi:10.1023/A:1016054904008

Luftman, J., Ben-Zvi, T., Dwivedi, R., \& Rigoni, E. H. (2010). IT governance: An alignment maturity perspective. International Journal of IT/Business Alignment and Governance, 1(2), 13-25.

MacGregor, R. C. (2004). Factors associated with formal networking in regional small business: Some findings from a study of Swedish SMEs. Journal of Small Business and Enterprise Development, 11(1), 60-74. doi:10.1108/14626000410519100

Mardikyan, S. (2010). Analyzing the usage of IT in SMEs. Communications of the IBIMA, 1-10. 
Mason, M., \& O’Mahony, J. (2008). Post-traditional Corporate Governance. Journal of Corporate Citizenship,31(31),31-44. doi:10.9774/GLEAF.4700.2008. au.00007

McGinnis, S. K., Pumphrey, L., Trimmer, K., \& Wiggins, C. (2004). Sustaining and extending organization strategy via information technology governance. 37th Annual Hawaii International Conference on System Sciences, Hawaii, 1-10. doi:10.1109/ HICSS.2004.1265390

Melville, N., Kraemer, K., \& Gurbaxani, V. (2004). Information technology and organizational performance: An integrative model of IT business value. Management Information Systems Quarterly, 28(2), 283-322.

Messabia, N., \& Elbekkali, A. (2010). Information technology governance: A stakeholder approach, An Enterprise Odyssey. International Conference Proceedings, Zagreb, Croatia, 979-997.

Messeghem, K. (2003). Strategic entrepreneurship and managerial activities in SMEs. International Small Business Journal, 21(2), 197-212. doi:10.1177/0266242603021002004

Mitchell, R. K., Agle, B. R., \& Wood, D. J. (1997). Toward a theory of stakeholder identification and salience: Defining the principle of who and what really counts. Academy of Management Review, 22(4), 853-886.

Mohamed, N., \& Singh, J. K. G. (2012). A conceptual framework for information technology governance effectiveness in private organizations. Information Management \& Computer Security, 20(2), 88-106. doi:10.1108/09685221211235616

Mohnnak, K. (2007). Innovation networks and capability building in the Australian high-technology SMEs. European Journal of Innovation Management, 10(2), 236-251. doi:10.1108/14601060710745279

Napoli, F. (2012). The effects of corporate governance processes of strategy change and value creation in small- or medium-sized firms: A study of family-owned firms in Italy. International Journal of Management, 29(3), 232-260.

Nfuka, E. N., \& Rusu, L. (2011). The effect of critical success factors on IT governance performance. Industrial Management \& Data Systems, 111(9), 1418-1448. doi:10.1108/02635571111182773
Nicholson, G. J., \& Kiel, G. C. (2007). Can directors impact performance? A case-based test of three theories of corporate governance. Corporate Governance, 15(4), 585-608. doi:10.1111/j.14678683.2007.00590.x

OECD (Ed.). (2005). SME and Entrepreneurship Outlook (p. 17). Paris: OECD.

Pekovic, S. (2010). The determinants of ISO 9000 certification: Acomparison of the manufacturing and service sectors. Journal of Economic Issues, XLIV(4), 895-914. doi:10.2753/JEI0021-3624440403

Peterson, R. (2004). Crafting information technology governance. Information Systems Management, 21(4), 7-22. doi:10.1201/1078/44705.21.4.200409 $01 / 84183.2$

Pollard, C. (2003). Exploring continued and discontinued use of IT: Acase study of OptionFinder, a group support system. Group Decision and Negotiation, 12(3), 171-193. doi:10.1023/A:1023314606762

Ramdani, B., Kawalek, P., \& Lorenzo, O. (2009). Knowledge management and enterprise systems adoption by SMEs: Predicting SMEs' adoption of enterprise systems. Journal of Enterprise Information Management, 22(1/2), 10-24. doi:10.1108/17410390910922796

Rasheed, H. S., \& Geiger, S. W. (2001). Determinants of governance structure for the electronic value chain: Resource dependency and transaction costs perspectives. The Journal of Business Strategy, 18(2), 159-176.

Rau, K. G. (2004). Effective governance of IT: Design objectives, roles, and relationships. Information Systems Management, 21(4), 35-42. doi:10.1201/1 078/44705.21.4.20040901/84185.4

Raymond, L., Bergeron, F., \& Rivard, S. (1998). Determinants of business process reengineering success in small and large enterprises: An empirical study in the Canadian context. Journal of Small Business Management, 36(1), 72-85.

Raymond, L., \& Croteau,A.-M. (2006). Enabling the strategic development of SMEs through advanced manufacturing systems: A configurational perspective. Industrial Management \& Data Systems, 106(7), 1012-1032. doi:10.1108/02635570610688904

Raymond, L., Uwizeyemungu, S., Bergeron, F., \& Gauvin, S. (2012). A framework for research on e-learning assimilation in SMEs: Astrategic perspective. European Journal of Training and Development, 36(6), 592-613. doi:10.1108/03090591211245503 
Ruivo, P., Oliveira, T., \& Neto, M. (2012). ERP use and value: Portuguese and Spanish SMEs. Industrial Management \& Data Systems, 112(7), 1008-1025. doi:10.1108/02635571211254998

Scupola, A. (2008). Conceptualizing competences in e-services adoption and assimilation in SMEs. Journal of Electronic Commerce in Organizations, 6(2), 78-91. doi:10.4018/jeco.2008040105

Sila, I., \& Dobni, D. (2012). Patterns of B2B e-commerce usage in SMEs. Industrial Management \& Data Systems, 112(8), 1255-1271. doi:10.1108/02635571211264654

Talaulicar, T. (2010). The concept of the balanced company and its implications for corporate governance. Society and Business Review, 5(3), 232-244. doi:10.1108/17465681011079464

Torrès, O., \& Julien, P.-A. (2005). Specificity and denaturing of small business. International Small Business Journal, 23(4), 355-377. doi:10.1177/0266242605054049

Turlea,E., Mocanu, M., \& Radu, C. (2010). Corporate governance in the banking industry. Accounting and Management Information Systems, 9(3), 379-402.

Uhlaner, L., Wright, M., \& Huse, M. (2007). Private firms and corporate governance: An integrated economic and management perspective. Small Business Economics, 29(3), 225-241. doi:10.1007/s11187006-9032-Z

van Gils, A. (2005). Management and governance in Dutch SMEs. European Management Journal, 23(5), 583-589. doi:10.1016/j.emj.2005.09.013

Van Grembergen, W., \& De Haes, S. (2010). A research journey into enterprise governance of IT, business/IT alignment and value creation. International Journal of IT/Business Alignment and Governance, 1(1), 1-13. doi:10.4018/jitbag.2010120401

Vogt, M., Küller, P., Hertweck, D., \& Hales, K. (2011). Adapting IT governance frameworks using domain specific requirements methods: Examples from small \& medium enterprises and emergency management. Proceedings of the 17th Americas Conference on Information Systems, Detroit, Michigan, August 4-7, 1-10.
Wainwright, D., Green, G., Mitchell, E., \& Yarrow, D. (2005). Towards a framework for benchmarking ICT practice, competence and performance in small firms. Performance Measurement and Metrics, 6(1), 39-52. doi:10.1108/14678040510588580

Weill, P., \& Ross, J. (2005). A matrixed approach to designing IT governance. Sloan Management Review, 46(2), 26-34.

Weill, P., \& Ross, J. W. (Eds.). (2004). ITgovernance: How top performers manage IT decision rights for superior results. Boston: Harvard Business School Press.

Wilkin, C. L. (2012). The role of IT governance practices in creating business value in SMEs. Journal of Organizational and End User Computing, 24(2), 1-17. doi:10.4018/joeuc.2012040101

Wilkin, C. L., Campbell, J., \& Moore, S. (2013). Creating value through governing IT deployment in a public/private-sector inter-organizational context: A human agency perspective. European Journal of Information Systems, 22(5), 498-511. doi:10.1057/ ejis. 2012.21

Xiaobao, P., Wei, S., \& Yuzhen, D. (2013). Framework of open innovation in SMEs in an emerging economy: Firm characteristics, network openness, and network information. International Journal of Technology Management, 62(2-4), 223-250. doi:10.1504/IJTM.2013.055142

Xue, Y., Liang, H., \& Boulton, W. R. (2008). Information technology governance in information technology investment decision processes: The impact of investment characteristics, external environment, and internal context. Management Information Systems Quarterly, 32(1), 67-96.

Zarvić, N., Stolze, C., Boehm, M., \& Thomas, O. (2012). Dependency-based IT Governance practices in inter-organizational collaborations: Agraph-driven elaboration. International Journal of Information Management, 32(6), 541-549. doi:10.1016/j.ijinfomgt.2012.03.004 